\title{
Șize and genomic location of the pMGA multigene family of Mycoplasma gallisepticum
}

\author{
Nina Baseggio, Michelle D. Glew, Philip F. Markham, Kevin G. Whithear \\ and Glenn F. Browning
}

Department of Veterinary Science, The University of Melbourne, Parkville, Victoria 3052, Australia

\author{
Author for correspondence: Nina Baseggio. Tel: +6139344 7368. Fax: +61393447374. \\ e-mail: vet_micro@muwayf.unimelb.edu.au
}

The pMGA multigene family encodes variant copies of the cell surface haemagglutinin of Mycoplasma gallisepticum. Quantitative Southern blotting, using an oligonucleotide probe complementary to a region conserved in the leader sequence of all known pMGA genes, was used to estimate the number of members of the family in the genome of seven strains of $M$. gallisepticum. The number of copies estimated to be present in the genome varied from 32 in strain $F$ to 70 in strain $R$, indicating that the PMGA gene family may be second in size only to the tRNA family among prokaryotes. If all members of the PMGA family are of similar length to those which have been characterized, a minimum of $79 \mathrm{~kb}(7.7 \%)$ of the genome of strain S6, $82 \mathrm{~kb}(8.2 \%)$ of PG31 and $168 \mathrm{~kb}(16 \%)$ of the genome of strain $R$ is dedicated to encoding variants of the same haemagglutinin. The GAA repeat motif identified in the intergenic region between all characterized PMGA genes appeared to be a feature common to most, if not all, pMGA genes, and furthermore probably exclusive to them. The genomic locations of members of the pMGA family were determined by PFGE and Southern blot hybridization of $M$. gallisepticum strain S6. The hybridizing regions were localized to four separate regions on the chromosome. The pMGA genes are likely to be predominantly arranged as tandem repeats within these regions, similar to the restricted regions for which the genomic sequence has been determined.

Keywords: Mycoplasma gallisepticum, mapping, adhesin, immune evasion, multigene family

\section{INTRODUCTION}

A common feature of diseases caused by mycoplasmas is their chronicity. However the basis of the pathogenesis of mycoplasmosis, and in particular the ability of such apparently defenceless organisms to persist in the face of an active immune response by the host, has resisted explanation. In recent years, variable expression of surface antigens has been observed in a number of mycoplasma species, resulting in the hypothesis that immune evasion may be an important part of the pathogenesis of mycoplasmosis (Wise, 1993). Among the species reported to exhibit such variable expression of antigens has been the major poultry pathogen, Mycoplasma gallisepticum (Bencina

The GenBank accession number for the nucleotide sequence of probe 3 reported in this paper is $\mathbf{L} 43361$. et al., 1994; Garcia et al., 1994; Markham et al., 1992, 1993; Yogev et al., 1994).

We recently characterized the major surface antigen and haemagglutinin (pMGA) of M. gallisepticum strain S6 and identified and characterized the gene encoding it. In the course of these investigations a number of homologous genes were identified, all of which appeared to be translationally competent. In all, four pMGA genes were completely characterized, and a further four were partially characterized (Markham, 1995; Markham et al., 1994). The regions which were sequenced consisted entirely of pMGA gene sequence, each gene being approximately $2 \cdot 1 \mathrm{~kb}$ in length and separated from the following pMGA gene by an intergenic region of about $350 \mathrm{bp}$. In the segments sequenced, all genes were arranged as tandem repeats. As much as $120 \mathrm{~kb}$ of the genome appears to contain pMGA genes, suggesting that as many as 50 fulllength genes may be present in the S6 genome if they are 
all arranged as tandem repeats in a single locus (Markham et al., 1994).

In further studies of the transcription of pMGA genes, we found that mRNAs encoding pMGA proteins are monocistronic, and that the vast majority of transcripts are derived from a single member of the family (Glew et al., 1995). In addition variation in expression of this gene has been shown to be influenced by exposure to antibody directed against pMGA (unpublished data). Thus, this multigene family has certain features that might be expected of an immune-evasion mechanism, namely selective expression of individual members of the family within different cells, and suppression of expression upon recognition by specific antibody.

In any study of the role of the pMGA family in the pathogenesis of mycoplasmosis, it is important to know the full genomic complement of pMGA genes. Furthermore, given the tandem arrangement of all known pMGA genes, it may be that the genomic organization of the family could explain the basis of control of expression of members of this family. Thus, the purpose of this study was to determine the number of members of the pMGA family in several epidemiologically distinct strains, and the genomic location and organization of pMGA loci in strain S6.

\section{METHODS}

Bacterial strains, cultural methods and preparation of DNA. The strains of $M$. gallisepticum used were S6, PG31, R, F, 80083, ts-11 and Ap3AS. PG31 (Edward \& Kanarek, 1960) was obtained from Geoff Cottew, CSIRO, Parkville, Victoria, Australia, and the derivation of the other strains has been described previously (Kleven et al., 1988a, b; Soeripto et al., 1989; Whithear et al., 1990). All strains were grown until lateexponential phase in mycoplasma broth medium (Frey et al., 1968) supplemented with $10 \%(\mathrm{v} / \mathrm{v})$ swine serum and cells were harvested by centrifugation at $16000 \mathrm{~g}$. Genomic DNA was prepared in agarose blocks. Briefly, cells were washed twice in PBS (140 mM NaCl, 2.7 mM KCl, $1.5 \mathrm{mM} \mathrm{KH}_{2} \mathrm{PO}_{4}, 8.1 \mathrm{mM}$ $\mathrm{Na}_{2} \mathrm{HPO}_{4}$ ) and then resuspended in PBS. The cell suspension was mixed with an equal volume of $2 \%(\mathrm{w} / \mathrm{v})$ low-meltingpoint agarose in $\mathrm{PBS}$ at $37^{\circ} \mathrm{C}$. The mixture was cast into blocks and allowed to set. The agarose blocks were incubated at $50{ }^{\circ} \mathrm{C}$ for 24-48 $\mathrm{h}$ in ESP solution [0.5 M EDTA, pH 9.2, $1 \%(\mathrm{w} / \mathrm{v})$ lauroyl sarcosine, $1 \mathrm{mg} \mathrm{ml}^{-1}$ Proteinase $\mathrm{K}$ ] with one change of solution. Plasmid DNA was purified using the method of Del Sal et al. (1988).

Restriction endonuclease digestion, electrophoresis and Southern blotting. Slices from agarose blocks that had previously been equilibrated in TE $(10 \mathrm{mM}$ Tris base, $1 \mathrm{mM}$ EDTA, adjusted to $\mathrm{pH} 8.0$ with $\mathrm{HCl}$ ) were incubated for $2 \mathrm{~h}$ in $100 \mu \mathrm{l}$ appropriate restriction endonuclease buffer supplied by the manufacturer. After substitution of fresh buffer, 8-30 U restriction endonuclease was added, and the mixtures were incubated at the recommended temperature for $18 \mathrm{~h}$.

The number of pMGA genes in the genome of $M$. gallisepticum strain S6 was determined using genomic DNA digested with EcoRI or ClaI. The validity of the approach was assessed by using a cloned $9.7 \mathrm{~kb}$ EcoRI fragment of the genome digested with Pst , BglII or EcoRI. In subsequent experiments to determine the number of pMGA genes in six other strains of $M$. gallisepticum, genomic DNA from each strain was digested with EcoRI. The agarose slices were melted at $60^{\circ} \mathrm{C}$ and loaded on $0.6 \%$ agarose gels. The DNA fragments were separated by continuous field electrophoresis in TPE buffer $(1.8 \mathrm{mM}$ Tris, $0.05 \mathrm{mM} \mathrm{Na}_{2}$ EDTA, $1.5 \mathrm{mM} \mathrm{NaH}_{2} \mathrm{PO}_{4}$ ) for $16 \mathrm{~h}$ at $2.5 \mathrm{~V} \mathrm{~cm}^{-1}$.

The location of pMGA genes on the chromosome of $M$. gallisepticum strain S6 was determined using genomic DNA digested with the restriction endonucleases BglI, SmaI, SalI, $X b_{o} \mathrm{I}$ and $E a g I$, and combinations of these enzymes. The agarose slices were loaded into $1 \%(\mathrm{w} / \mathrm{v})$ agarose, $0.5 \times \mathrm{TBE}(1 \times \mathrm{TBE}$ $=89 \mathrm{mM}$ Tris, $89 \mathrm{mM}$ boric acid, $2 \mathrm{mM}$ EDTA, $\mathrm{pH} 8.3$ ) gels and the DNA fragments were separated by clamped homogeneous electric field electrophoresis using a Bio-Rad CHEF DRIII. Electrophoresis parameters were varied to ensure maximum separation over required size ranges.

For Southern blots, gels were treated twice in $0.25 \mathrm{M} \mathrm{HCl}$ for $10 \mathrm{~min}$, and then in $0.4 \mathrm{M} \mathrm{NaOH}$ for a further $15 \mathrm{~min}$. DNA transfer onto Hybond $\mathrm{N}^{+}$membranes (Amersham) was achieved using $20 \times \mathrm{SSC}(3 \mathrm{M} \mathrm{NaCl}, 300 \mathrm{mM}$ sodium citrate).

Hybridization to PMGA gene probes. To determine the number of pMGA genes in the genome the blots were hybridized to an oligonucleotide probe, Oligo1 (5'-ACGAACCAATACC'TAATAAACTAACAAA-3') complementary to a coding sequence conserved in all characterized pMGA genes, with the exception of the PMGA1.1 gene which has a single base-pair mismatch when hybridized with Oligo1. The probe was radiolabelled by $5^{\prime}$-phosphorylation using polynucleotide kinase in the presence of $\left[\gamma^{32} \mathrm{P}\right]$ ATP. Hybridization to this probe was for $16 \mathrm{~h}$ at $50^{\circ} \mathrm{C}$ in Church buffer (Church \& Gilbert, 1984). Membranes were washed twice in $6 \times \mathrm{SSC}, 0.5 \%(\mathrm{w} / \mathrm{v})$ $\mathrm{SDS}$, at $60^{\circ} \mathrm{C}$, then autoradiographed. Direct quantitative analysis of the membranes was performed using a Molecular Dynamics 400 series phosphorimager and subsequent analysis was with ImageQuant software. A second oligonucleotide, Oligo2 (5'-GAAGAAGAAGAAGAAGAAGAAGAA-3') that hybridizes to an intergenic repeat motif found between all characterized pMGA genes, was used as a probe under the hybridization conditions described above, except that membranes were washed at $50{ }^{\circ} \mathrm{C}$.

In experiments to determine the genomic location of pMGA genes in the $\mathrm{S} 6$ strain of $M$. gallisepticum the membranes were hybridized to three probes derived from cloned genomic fragments of the $\mathrm{S} 6$ strain. Confirmation that the cloned fragments contained members of the pMGA gene family was determined by DNA sequence comparisons. Probe 1 was a $3 \mathrm{~kb}$ Pst I-EcoRI fragment containing most of the pMGA1.1 gene (Markham et al., 1994). Probe 2 contained the $5^{\prime}$ end of the pMGA1.2 gene of strain S6, extending from nucleotide position 177 to position 1409 (Markham et al., 1993). Probe 3 was a $16 \mathrm{~kb}$ ClaI fragment that contained a 'pMGA-like' gene obtained by hybridization screening of a genomic library using probe 2 . Membranes were hybridized with probes labelled by random hexanucleotide priming of DNA synthesis in the presence of $[\alpha-$ $\left.{ }^{32} \mathrm{P}\right] \mathrm{dCTP}$. Hybridizations were for $16 \mathrm{~h}$ at $50^{\circ} \mathrm{C}$ in a buffer containing $6 \times \mathrm{SSC}, 0.5 \% \mathrm{SDS}, 5 \times$ Denhardt's solution and $100 \mu \mathrm{g} \mathrm{ml}^{-1}$ denatured salmon sperm DNA. Membranes were washed twice under medium-stringency conditions $(1 \times \mathrm{SSC}$, $0.5 \% \mathrm{SDS}$, at $50^{\circ} \mathrm{C}$ ), or under high-stringency conditions $\left(0.1 \times \mathrm{SSC}, 0 \cdot 1 \% \mathrm{SDS}\right.$, at $\left.60^{\circ} \mathrm{C}\right)$, and then autoradiographed. Under medium-stringency conditions all cross-hybridizing, pMGA-gene-carrying fragments were detected, while under high-stringency conditions those fragments containing the probe sequence could be identified. These data enabled the linking of restriction fragments that contained the probes. 


\section{RESULTS}

\section{Number of pMGA genes in the $\mathbf{5 6}$ genome}

A cloned fragment of the $M$. gallisepticum genome which had been fully sequenced was used to assess the correlation between the intensity of the radioactive signal, as determined by phosphorimaging, and the number of copies of the conserved PMGA gene sequence on the Southern blot. Fragments containing one, two, three or four copies of the sequence were probed with oligonucleotide Oligo1, as shown in Fig. 1. The intensity of the signal from each fragment displayed a linear relationship between the number of copies of the sequence and the level of radioactivity.

The hybridization of the oligonucleotide Oligo1 to S6 genomic DNA digested with EcoRI or ClaI is presented in Fig. 1. The intensity of the signal from each distinguishable band was determined for three replicate lanes on the same blot and the mean signal was determined as shown in Table 1. Using the $9.7 \mathrm{~kb}$ EcoRI fragment [which from sequencing studies was known to contain four copies of

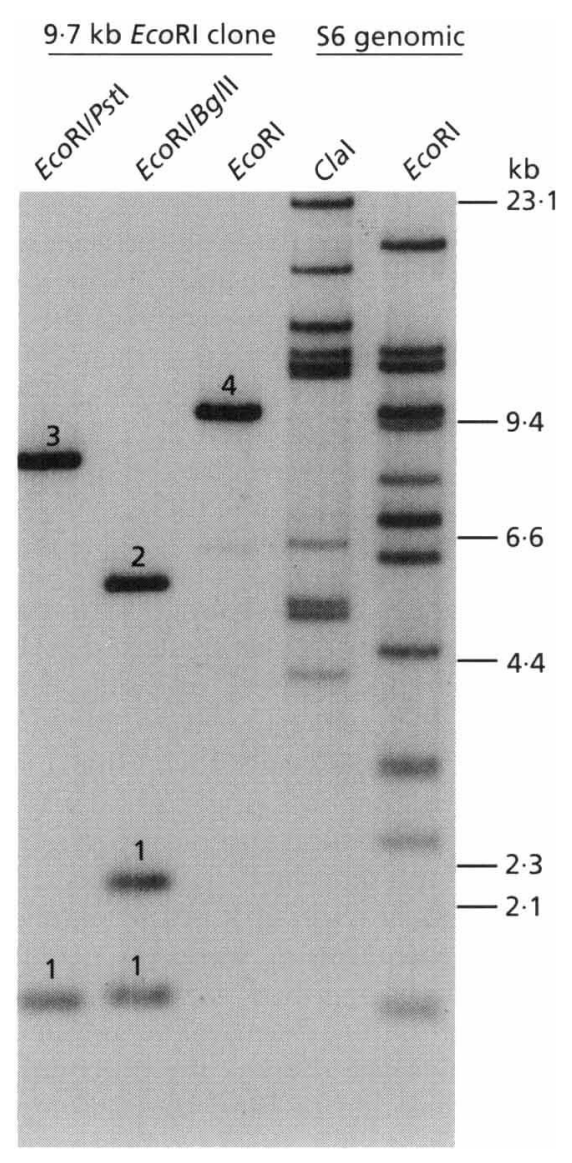

Fig. 1. Southern blot of S6 DNA probed with oligonucleotide Oligo1. The first three lanes contain the cloned $9.7 \mathrm{~kb}$ EcoRI fragment and the last two lanes contain S6 genomic DNA, digested with the restriction enzymes shown. The number of copies of the Oligo1 sequence in each of the fragments is marked on the figure. Hindlli-digested lambda DNA was used as size markers.
Table 1. Quantification of pMGA gene copy-number in M. gallisepticum $\mathrm{S6}$

\begin{tabular}{|c|c|c|c|}
\hline \multirow{2}{*}{$\begin{array}{l}\text { Restriction } \\
\text { enzyme }\end{array}$} & \multicolumn{2}{|c|}{ Digestion products } & \multirow{2}{*}{$\begin{array}{l}\text { Number } \\
\text { of copies } t\end{array}$} \\
\hline & $\begin{array}{c}\text { Fragment size } \\
(\mathbf{k b})\end{array}$ & Mean area* & \\
\hline \multirow[t]{11}{*}{ EcoRI } & 18 & 2034 & $3 \cdot 2(3)$ \\
\hline & $12 \cdot 2$ & 1781 & $2 \cdot 8(3)$ \\
\hline & $11 \cdot 4$ & 1965 & $3 \cdot 1(3)$ \\
\hline & $9 \cdot 7,9 \cdot 3$ & 3845 & $6.0(6)$ \\
\hline & $7 \cdot 8$ & 1427 & $2 \cdot 2(2)$ \\
\hline & $7 \cdot 0$ & 2677 & $4 \cdot 2(4)$ \\
\hline & $6 \cdot 3$ & 1944 & $3.0(3)$ \\
\hline & $4 \cdot 7$ & 1672 & $2 \cdot 6(3)$ \\
\hline & $3 \cdot 4,3 \cdot 2$ & 1895 & $3 \cdot 0(3)$ \\
\hline & $2 \cdot 6$ & 882 & $1 \cdot 4(1)$ \\
\hline & $1 \cdot 4$ & 1253 & $2 \cdot 0(2)$ \\
\hline Total... & 97 & 21375 & 33.4 (33) \\
\hline \multirow[t]{7}{*}{ ClaI } & 22 & 2031 & $4 \cdot 0(4)$ \\
\hline & 16 & 1952 & $3 \cdot 8(4)$ \\
\hline & $13 \cdot 2$ & 2679 & $5 \cdot 3(5)$ \\
\hline & $11 \cdot 9,11 \cdot 4,10 \cdot 9$ & 4660 & $9 \cdot 2(9)$ \\
\hline & 6.5 & 854 & $1 \cdot 7(2)$ \\
\hline & $5 \cdot 4,5 \cdot 2$ & 2469 & $4.9(5)$ \\
\hline & $4 \cdot 3$ & 767 & $1.5(2)$ \\
\hline Total... & 107 & 15412 & $30 \cdot 4(31)$ \\
\hline
\end{tabular}

* The mean area represents the mean integrated area under the signal peak produced by the fragment(s) indicated.

t The number of copies of pMGA is listed, and the nearest whole number is in parentheses.

the sequence (Markham et al., 1994)] as an internal standard the number of copies of the sequence in each band was estimated (Table 1). The $9.3 \mathrm{~kb}$ EcoRI fragment produced a signal peak half the size of the $9.7 \mathrm{~kb}$ EcoRI fragment and thus was deemed to contain two copies of pMGA. As the signals from both the 9.7 and the $9.3 \mathrm{~kb}$ EcoRI fragments were incompletely resolved, it was considered more accurate to combine their signals and assume the mean area represented a total of six copies of pMGA (Table 1). A $0.3 \mathrm{~kb}$ EcoRI fragment which also hybridized to Oligo1 was not included in this analysis because the signal observed was too weak and diffuse to enable it to be clearly defined from the background. The $22 \mathrm{~kb} \mathrm{ClaI}$ fragment was known from restriction analysis to contain the $9.7 \mathrm{~kb}$ EcoRI fragment and so possessed at least four copies of pMGA (Table 1). A total of 33 copies of the sequence were estimated to be present in the genome using the data from the EcoRI digestion, and 3.1 copies were estimated to be present using the data from the ClaI digestion. If the $22 \mathrm{~kb} \mathrm{ClaI}$ fragment was assumed to contain five copies of the sequence, as could be inferred from sequence data (Markham et al., 1994), then 38 copies were estimated to be present using the ClaI digestion data. Similar estimates of the sequence copy-number were obtained from the EcoRI digestion data by determining the mean signal per copy by assuming the bands with the 
(a)

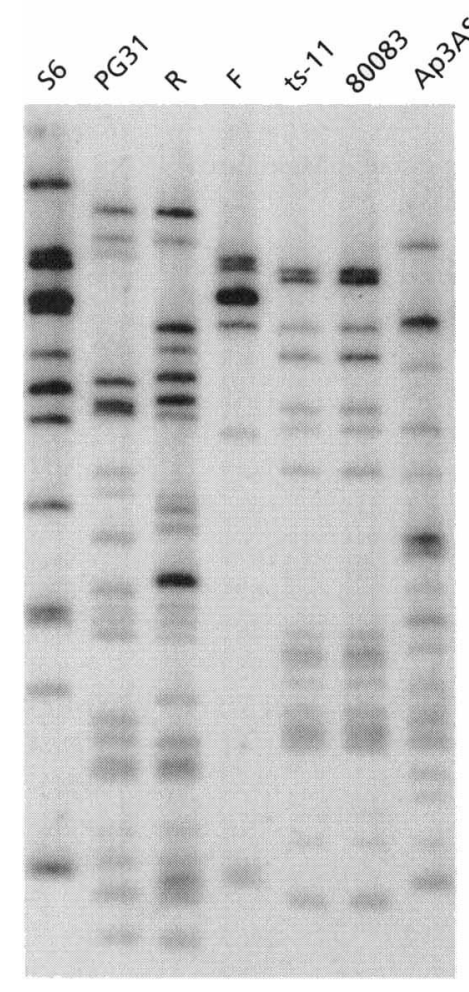

(b)

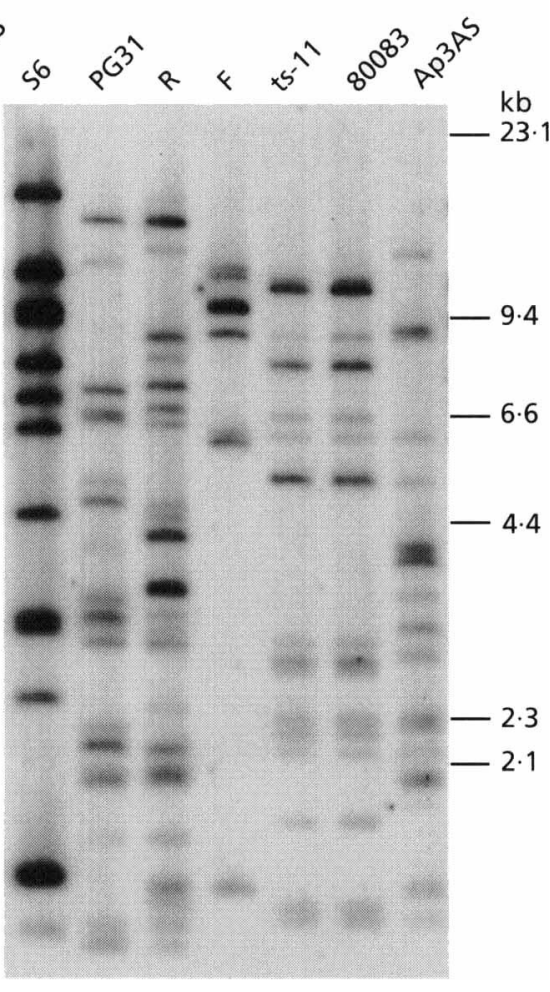

Fig. 2. Southern blots of $M$. gallisepticum strains hybridized with oligonucleotide probes. EcoRI-digested genomic DNA of strains (as indicated above each lane) were probed with oligonucleotides Oligo1 (a) and Oligo2 (b). HindllI-digested lambda DNA was used as size markers.
Table 2. Quantification of PMGA gene copy-number in M. gallisepticum strains

\begin{tabular}{|lcc|}
\hline Strain & $\begin{array}{c}\text { Estimated no. } \\
\text { copies pMGA* }\end{array}$ & $\begin{array}{c}\text { Total DNA } \\
\text { (kb) } \dagger\end{array}$ \\
\hline S6 & 33 & 79 \\
PG31 & 34 & 82 \\
R & 70 & 168 \\
F & 32 & 77 \\
80083 & 41 & 98 \\
ts-11 & 34 & 82 \\
Ap3AS & 48 & 115 \\
\hline
\end{tabular}

* Copy number was determined by hybridizing EcoRI-restricted genomic DNA with the Oligol oligonucleotide probe.

† Total DNA was calculated by assuming each gene copy required $2.4 \mathrm{~kb}$ DNA containing the coding and intergenic sequences.

weakest signal corresponded to fragments containing a single copy and those with signals approximately twice this to fragments containing two copies.

An autoradiograph of the blot of genomic DNA of S6 and the six other strains of $M$. gallisepticum digested with EcoRI and probed with the oligonucleotide probe Oligo1, is shown in Fig. 2(a). The intensity of the signal from each distinguishable band was determined for two replicate lanes on the same blot and the mean signal was determined to estimate the number of copies of pMGA in each strain. The total number of copies of the sequence in the genome of each strain was estimated by using the integrated value for a selected DNA species, the size of which precluded possession of any more than one copy of the conserved pMGA signal sequence (that is less than $2 \cdot 4 \mathrm{~kb}$ ). The estimated number of copies of the sequence ranged from 32 in strain F to 70 in strain $R$ (Table 2). The hybridization patterns for each of the seven strains were unique with the exception of ts- 11 and its parent 80083 which appeared to be identical (Fig. 2a).

The second oligonucleotide, Oligo2, hybridizes to the region located upstream to the structural pMGA gene that contains a variable number of GAA trinucleotide repeats. The hybridization patterns of all seven strains were very similar when using either Oligo1 or Oligo2 oligonucleotides as probes (Fig. 2). This similarity suggested that Oligo1 bound specifically to genes within the pMGA family and that the GAA repeats are a feature common to most, if not all, pMGA genes in $M$. gallisepticum and furthermore were restricted to these genes. The membrane probed with the Oligo2 oligonucleotide was not used to estimate the number of copies of pMGA genes because there is the potential for more than one oligonucleotide to bind to a single stretch of GAA repeats. Indeed, this most probably explains the increased intensities of some of the common bands when probed with Oligo2. The other apparent difference in the hybridization patterns was the occurrence of fragments which only hybridized to one of the oligonucleotide probes. The presence of an EcoRI site situated between the two sites of oligonucleotide hybridization offers the most plausible explanation. This is supported by the 
(a)

(b)
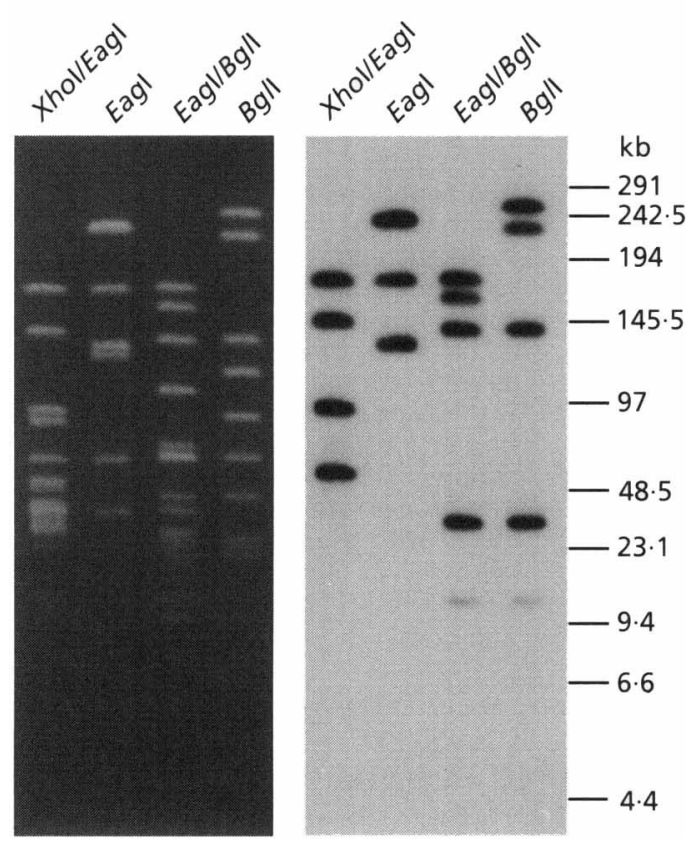

Fig. 3. (a) PFGE of restricted $M$. gallisepticum strain $\$ 6$ genomic DNA. Electrophoresis conditions used: $1 \%(w / v)$ agarose gel, initial switch time $0.3 \mathrm{~s}$, final switch time $21.8 \mathrm{~s}$, temperature $14^{\circ} \mathrm{C}$ with a run time of $19 \mathrm{~h}$. DNA fragment sizes were estimated using lambda concatamers and Hindlll-digested lambda DNA. (b) Southern blot of gel in (a), hybridized with probe 2 and washed under medium-stringency conditions (see Methods).

presence of some fragments that contain only one copy of pMGA using Oligo1 and are not detected by Oligo2.

\section{Genomic location of members of the pMGA gene family in strain $\mathbf{S 6}$}

It was of interest to locate the pMGA genes on the S6 chromosome as the identity of the expressed pMGA gene was known and its sequence has been determined (Markham et al., 1994). In addition, there were two restriction maps available for the $\mathrm{S} 6$ chromosome to aid mapping the multigene family (Chen, 1992; Gorton et al., 1995). The fragments of the strain S6 genome which hybridized to the pMGA gene probes were determined by comparison of photographs of the ethidium bromide stained gels to the autoradiographs of the blot of the gel after hybridization. An example of the data is shown in Fig. 3. The estimated sizes of fragments hybridizing to the pMGA gene probes are shown in Table 3. The restriction fragments are identified by the convention of alphabetically labelling them from largest to smallest. These data were used to establish restriction endonuclease maps for the regions of the genome containing pMGA genes. The pMGA multigene family was present on the two largest $S$ maI fragments $S m A$ and $S m B$, which together represented over half of the total S6 genome. Finer mapping using double-digests and high-stringency
Table 3. Restriction fragments from $M$. gallisepticum strain $\mathbf{6 6}$ that hybridize to pMGA gene probes

\begin{tabular}{|c|c|c|c|}
\hline Enzyme & Fragment & Size $(\mathbf{k b})$ & $\begin{array}{c}\text { Specific } \\
\text { probe }(s) *\end{array}$ \\
\hline \multirow[t]{5}{*}{$B g / \mathrm{I}$} & $\mathrm{BgA}$ & 265 & 2 \\
\hline & $\mathrm{BgB}$ & 227 & 3 \\
\hline & $\mathrm{BgC}$ & 135 & \\
\hline & $\mathrm{BgH}$ & 28 & 1 \\
\hline & $\mathrm{BgK}$ & 12 & \\
\hline \multirow[t]{4}{*}{ EagI } & $\mathrm{EgA1} \uparrow$ & 240 & 3 \\
\hline & $\mathrm{EgA} 2 \dagger$ & 240 & \\
\hline & $\mathrm{EgB}$ & 170 & 2 \\
\hline & $\mathrm{EgD}$ & 130 & 1 \\
\hline \multirow[t]{5}{*}{ SalI } & SIA & 140 & $3 \ddagger$ \\
\hline & SlB & 126 & 2 \\
\hline & SID & 79 & \\
\hline & $\mathrm{SlF}$ & 60 & 1 \\
\hline & $\mathrm{SlG}$ & 55 & $3 \ddagger$ \\
\hline \multirow[t]{2}{*}{$S m a \mathbf{I}$} & $\operatorname{Sm} A$ & 340 & 1,3 \\
\hline & $\mathrm{SmB}$ & 282 & 2 \\
\hline \multirow[t]{4}{*}{$X b o I$} & XhA & 250 & 2 \\
\hline & $\mathrm{XhB}$ & 176 & 1 \\
\hline & $\mathrm{XhC}$ & 145 & 3 \\
\hline & $\mathrm{XhF} 2 \Omega$ & 50 & \\
\hline
\end{tabular}

* Fragments which hybridize after high-stringency washes.

† Both EgA1 and EgA2 fragments of $240 \mathrm{~kb}$ hybridize to the pMGA gene probes.

$\ddagger$ Probe 3 contains a SalI site.

§Only one of the two $50 \mathrm{~kb}$ XhoI fragments hybridize to the pMGA gene probes.

washes of membranes identified four distinct regions to which the pMGA genes were located. Use of the three probes with high-stringency washes enabled the linkage of restriction fragments (Table 3). The regions of the map to which the pMGA genes hybridized are shown in Fig. 4. The pMGA multigene family extended over $597 \mathrm{~kb}$ of the $1030 \mathrm{~kb}$ S6 chromosome with the loci confined to four distinct regions totalling $312 \mathrm{~kb}$.

\section{DISCUSSION}

The work described in this paper has determined that the pMGA multigene family is second only in size to the tRNA family amongst prokaryotes and that the pMGA genes are clustered in four regions on the chromosome of S6. The genomic sizes of $M$. gallisepticum strains S6, PG31 and $\mathrm{R}$ range from 998 to $1054 \mathrm{~kb}$ (Chen, 1992; Gorton et al., 1995; Tigges \& Minion, 1994). It is remarkable that such a large multigene family should be present within one of the most genetically simple bacteria. Assuming the size of all pMGA genes to be similar to the four for which the complete sequence has been determined $(2.4 \mathrm{~kb})$, approximately $79 \mathrm{~kb}(7 \cdot 7 \%)$ of the genome of $M$. gallisepticum strain S6 encodes variants of this one surface 


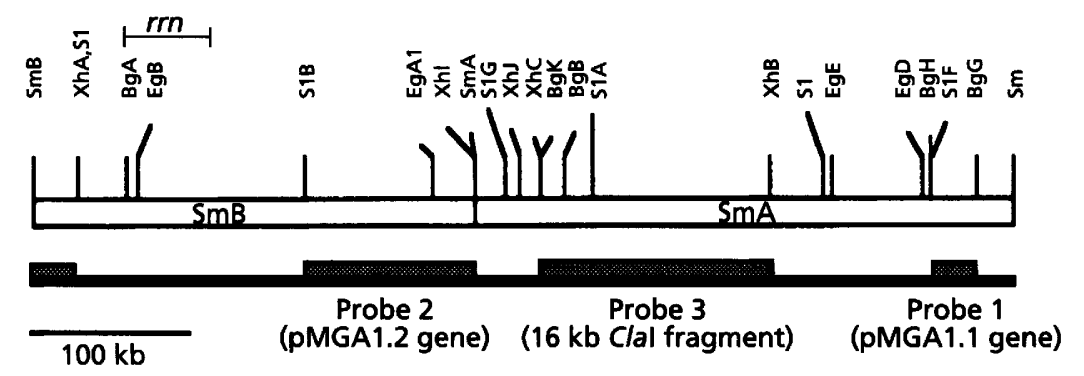

Fig. 4. Location of the PMGA multigene family on the SmA and SmB fragments of the $M$. gallisepticum strain $\mathrm{S} 6$ chromosome. Restriction endonuclease sites for Smal (Sm), Bgll (Bg), Eagl (Eg), Sall (SI), and Xhol (Xh) are mapped. The location of known fragments are followed by a capital letter assigned on the basis of size and the fragment extends rightward from that site to the next site of the particular restriction endonuclease. Some sites for Sall and Eagl occurring outside the pMGA loci were not determined and are not shown on the map. The location of the ribosomal RNA operon $(r r n)$ is indicated above the map. The four regions of the S6 genome that hybridize to the probes are indicated by the hatched boxes, with the specific binding probe listed below.

protein. For PG $31,82 \mathrm{~kb}(8.2 \%)$ of the genome is dedicated to encoding $\mathrm{pMGA}$. Strain $\mathrm{R}$ has up to 70 copies of pMGA that would account for $168 \mathrm{~kb}$ or approximately one-sixth of the genome. It is interesting to note that the two most virulent strains used in our study, $\mathrm{R}$ and Ap3AS, also possessed the largest pMGA complement. The association of virulence and pMGA copy number will require further investigation. The second largest multigene family thus far characterized in prokaryotes is the dor gene family of Desulfovibrio vulgaris Hildenborough which has 16 members (Deckers \& Voordouw, 1994). All the M. gallisepticum strains used in this investigation had at least 32 members, and in some strains the size of the pMGA family approached that of the tRNA gene family of Escherichia coli (Komine et al., 1990).

There are two available restriction maps for $M$. gallisepticum strain S6 (Chen, 1992; Gorton et al., 1995). The only restriction endonuclease used in common for mapping by both was $S m a$ I. Unfortunately, the relative order of $S m a I$ fragments differ, although the size estimates of the fragments are similar. The discrepancy in the maps in the region of the pMGA loci is in the relative positions of SmA and SmB fragments. In the map by Chen (1992) the $\mathrm{SmA}$ and $\mathrm{SmB}$ fragments are adjacent (as depicted in Fig. 4), while the map by Gorton et al. (1995) has the $10 \mathrm{~kb}$ SmG fragment separating SmA and SmB. The location of SmG, which does not contain any pMGA genes, does not affect the mapping data we present in this paper. This investigation was unable to provide evidence to support either map, as our data can be placed on both.

The conclusions drawn from this study assumed that the conserved sequence on which the oligonucleotide probe was based, occurred once in all members of the pMGA family and the oligonucleotide probe bound equally well to each copy. The validity of these assumptions was supported by further analysis of the data generated in the study. Firstly, comparison of the number of pMGA genes estimated to be present in each EcoRI fragment of the strain $\$ 6$ genome to the size of the fragment revealed that only one fragment was estimated to contain more pMGA genes than its size would allow. Indeed, in most cases the fragments were estimated to contain the same number of pMGA genes as would be predicted if they were composed entirely of tandem repeats of members of the pMGA family. Secondly, the concordance between the hybridization patterns produced by Oligol (based upon the consensus pMGA leader sequence) and Oligo2 (encompassing the GAA repeats) was excellent (Fig. 2). Very few fragments deviated between the two. Thirdly, the mapping studies showed that the pMGA-like regions were clustered on the genome, as would be expected if the family members were predominantly organized as tandem repeats, as seen in the regions of the pMGA locus which had been sequenced. This analysis not only supports the validity of the assumptions, but also implies that the findings established from restricted sequencing of the pMGA gene family are representative of the family as a whole.

These studies have demonstrated that the size of the pMGA family varied considerably between strains. Examination of the sequence of several pMGA genes revealed that each gene was bracketed by a variable number of tandem repeats of the sequence GAA. The presence of GAA repeats contribute to an open structure in supercoiled DNA (Hanvey et al., 1988), and thus it may be that these repeats, which are adjacent to the site of transcriptional initiation, serve a role in transcriptional regulation. Our data indicates that the GAA repeats are present in the putative regulatory DNA of all the members of the pMGA gene family and are probably unique to them. It may be that this region also serves as a site for frequent recombination events which facilitate gene duplication and deletion. Such events would account for the clustering of pMGA genes on the genome.

Only one pMGA gene appears to be expressed at one time, and the basis of this selective expression is control of transcription (Glew et al., 1995). However, there was no evidence from these studies that the expressed gene, pMGA1.1, had a unique location in the genome which may account for its selective transcription. Furthermore, other studies, conducted within our laboratory, failed to 
find any evidence for genomic rearrangement in the region of the expressed gene. Thus, the explanation for selective transcription of individual pMGA genes would appear to lie in the intergenic region immediately adjacent to the expressed gene.

The size of the pMGA gene family, the circumstantial evidence that most, if not all, members of the family are a similar size, and the apparent translational competence of all characterized genes in previous studies, point to the significance of this multigene family, and the structures it encodes, to the survival of $M$. gallisepticum. The ability to present up to 70 different variants of an adhesin to the host immune system could be predicted to offer a considerable advantage to a pathogen.

\section{ACKNOWLEDGEMENTS}

This work was supported by Australian Research Council Small and Collaborative Research Grants, and Bioproperties (Australia) Pty. Ltd. We thank Dr Ian D. Walker for helpful discussions during the preparation of this manuscript, and The Ludwig Institute For Cancer Research (Melbourne, Australia) for allowing use of their phosphorimager.

\section{REFERENCES}

Bencina, D., Kleven, S. H., Elfaki, M. G., Snoj, A., Dovc, P., Dorrer, D. \& Russ, I. (1994). Variable expression of epitopes on the surface of Mycoplasma gallisepticum demonstrated with monoclonal antibodies. Avian Pathol 23, 19-36.

Chen, X. (1992). Physical maps of genomes of Mycoplasma gallisepticum $P G 31$ and $S 6$ with some functional loci. $\mathrm{PhD}$ thesis, University of Melbourne.

Church, G. M. \& Gilbert, W. (1984). Genomic sequencing. Proc Natl Acad Sci US A 81, 1991-1995.

Deckers, H. M. \& Voordouw, G. (1994). Identification of a large family of genes for putative chemoreceptor proteins in an ordered library of the Desulfovibrio vulgaris Hildenborough genome. $J$ Bacteriol 176, 351-358.

Del Sal, G., Manfidetti, G. \& Schneider, C. (1988). A one-tube plasmid DNA mini-preparation suitable for sequencing. Nucleic Acids Res 16, 9878.

Edward, D. E. f. f. \& Kanarek, A. D. (1960). Organisms of the pleuropneumonia group of avian origin: their classification into species. Ann NY Acad Sci 79, 696-702.

Frey, M. L., Hanson, R. P. \& Anderson, D. P. (1968). A medium for the isolation of avian mycoplasmas. Am J Vet Res 29, 2163-2171.

Garcia, M., Elfaki, M. G. \& Kleven, S. H. (1994). Analysis of the variability in expression of Mycoplasma gallisepticum surface antigens. Vet Microbiol 42, 147-158.

Glew, M. D., Markham, P. F., Browning, G. F. \& Walker, I. D. (1995). Expression studies on four members of the pMGA multigene family in Mycoplasma gallisepticum S6. Microbiology 141, 3005-3014.

Gorton, T. S., Goh, M. S. \& Geary, S. J. (1995). Physical mapping of the Mycoplasma gallisepticum S6 genome with localization of selected genes. J Bacteriol 177, 259-263.

Hanvey, J. C., Klysik, J. \& Wells, R. D. (1988). Influence of DNA sequence on the formation of non-B right-handed helices in oligopurine-oligopyrimidine inserts in plasmids. $J$ Biol Chem 263, 7386-7396.

Kleven, S. H., Browning, G. F., Bulach, D. M., Ghiocas, E., Morrow, C. J. \& Whithear, K. G. (1988a). Examination of Mycoplasma gallisepticum strains using restriction endonuclease DNA analysis and DNA-DNA hybridisation. Avian Pathol 17, 559-570.

Kleven, S. H., Morrow, C. J. \& Whithear, K. G. (1988b). Comparison of Mycoplasma gallisepticum strains by hemagglutinationinhibition and restriction endonuclease analysis. Avian Dis 32, 731-741.

Komine, Y., Adachi, T., Inokuchi, H. \& Ozeki, H. (1990). Genomic organization and physical mapping of the transfer RNA genes in Escherichia coli K12. J Mol Biol 212, 579-598.

Markham, P. F. (1995). The $p M G A$ gene repertoire of Mycoplasma gallisepticum. $\mathrm{PhD}$ thesis, University of Melbourne.

Markham, P. F., Glew, M. D., Brandon, M. R., Walker, I. D. \& Whithear, K. G. (1992). Characterization of a major hemagglutinin protein from Mycoplasma gallisepticum. Infect Immun 60, 3885-3891.

Markham, P. F., Glew, M. D., Whithear, K. G. \& Walker, I. D. (1993). Molecular cloning of a member of the gene family that encodes pMGA, a hemagglutinin of Mycoplasma gallisepticum. Infect Immun 61, 903-909.

Markham, P. F., Glew, M. D., Sykes, J. E., Bowden, T. R., Pollocks, T. D., Browning, G. F., Whithear, K. G. \& Walker, I. D. (1994). The organisation of the multigene family which encodes the major cell surface protein, pMGA, of Mycoplasma gallisepticum. FEBS Lett 352, $347-352$.

Soeripto, Whithear, K. G., Cottew, G. S. \& Harrigan, K. E. (1989). Virulence and transmissibility of Mycoplasma gallisepticum. Aust Vet J 66, 65-72.

Tigges, E. \& Minion, F. C. (1994). Physical map of Mycoplasma gallisepticum. J Bacteriol 176, 4157-4159.

Whithear, K. G., Soeripto, Harrigan, K. E. \& Ghiocas, E. (1990). Safety of temperature sensitive mutant Mycoplasma gallisepticum vaccine. Aust Vet J 67, 159-165.

Wise, K. S. (1993). Adaptive surface variation in mycoplasmas. Trends Microbiol 1, 59-63.

Yogev, D., Menaker, D., Strutzberg, K., Levisohn, S., Kirchhoff, H., Hinz, K.-H. \& Rosengarten, R. (1994). A surface epitope undergoing high-frequency phase variation is shared by Mycoplasma gallisepticum and Mycoplasma bovis. Infect Immun 62, 4962-4968.

Received 14 November 1995; revised 21 December 1995; accepted 11 January 1996. 